\title{
THE IMPACT OF A CHANGE IN THE POSITION OF THE REGIONAL TECHNICAL IMPLEMENTATION UNIT (UPTD) IN THE EDUCATION SECTOR TOWARDS THE QUALITY OF SECONDARY SCHOOL EDUCATION SERVICES IN EAST NUSA TENGGARA PROVINCE, INDONESIA
}

\author{
Ali Hendi Riswandi ${ }^{*}$, Kase Petrus, Nursalam \\ Master's Program of Administrative Science, University of Nusa Cendana, \\ Nusa Tenggara Timur, Indonesia \\ *E-mail: hendi riswandi@yahoo.com
}

\begin{abstract}
The purpose of this study was to describe and analyze the positive and negative impact of policy implementation that is changing the position of UPTD ${ }^{1}$ in the education sector towards the services it provides to teachers and education personnel in East Nusa Tenggara Province. This study used a descriptive method with a qualitative approach. The study was carried out in schools in East Nusa Tenggara Province with specific considerations. Data for this study was collected using interviews, documentation, and observations. Data collected were primary and secondary data. We used the data analysis technique proposed by Miles and Huberman (2007). Data validation was done using the triangulation technique. The results of the study indicated that the change in the position of UPTD in the education sector negatively affected secondary school education services in East Nusa Tenggara Province assessed on the following dimensions: (1) impact on the target groups, (2) impact on non-target groups, (3) impact on current and future condition, and (4) impact on costs.
\end{abstract}

\section{KEY WORDS}

Impact, implementation, policy, education, quality of services.

Starting on January 1, 2017, and referring to Law Number 23 of 2014 concerning Regional Government, a transfer of authority in education affairs occurred, where the provincial government was given the authority to manage education, especially at the secondary levels (SMA, SMK, and SMALB) ${ }^{2}$. Previously, the matter was managed by the regency or city government. Since the change in authority, as a first step to providing quality education services, the Provincial Government of East Nusa Tenggara has issued Regional Regulation Number 9 of 2016 concerning the Formation and Structure of Regional Officials where the regional regulation regulates the position and functions of the Regional Technical Implementation Unit (UPTD) in the education sector abbreviated as UPTD in the education sector. The position of UPTD in the education sector is explained in article 2-it is an element implementing technical activities supporting the education office, especially in terms of education. In addition, UPTD in the education sector is also led by an official head with an echelon III-b rank, whose position is under and responsible to the Head of the Education Office.

The Regional Regulation Number 9 of 2016 regulates some official regional organizations in the East Nusa Tenggara Province. Education is part of mandatory government affairs related to basic services, and it is described in detail in article 6 of the regulation, where the education office can form certain UPTD to carry out operational and/or supporting technical activities with a working area covering one or several regencies/cities. UPTD, as referred to in paragraph 1, is part of the regional office responsible to the Head of the Education Office. Based on article 3 of the Regional Regulation Number 9 of 2016, UPTD in the education sector is divided into 12 UPTDs based on each region's characteristics, shape, and area. This division helps each educational unit to get fast and good service. When referring to Ministerial Regulation Number 17 of 2010 article 3 concerning Education

\footnotetext{
${ }_{1}^{1}$ Regional Technical Implementation Unit (UPTD) is an institution that implements government policies in regional (regency/city) level.

2 SMA (Sekolah Menengah Atas) or Public Senior High School; SMK (Sekolah Menengah Kejuruan) or Vocational School; SMKLB (Sekolah Menengah Atas Luar Biasa) or Senior High School for Students with Special Needs
} 
Management, the management of education aims to ensure public access to adequate, equitable, and reachable educational services to improve the quality, competitiveness, effectiveness, efficiency, and accountability of education. Therefore, the formation of UPTD in the education sector is the best choice to make.

In the workflow of UPTD in the education sector, the Regional Regulation Number 9 of 2016 mandates that several administrative matters for teachers and education personnel, such as managing employee performance targets, periodic salary increases, and permits (leave), can be handled directly by the head of UPTD in the education sector, except for administration related to promotion and transfer of teachers and education personnel within the region. Promotion and transfer must be approved by the Head of Education Office and approved by the Regional Secretariat or the Governor because the head of UPTD in the education sector is only entitled to check the completeness of documents following the applicable requirements. After being declared complete, the proposal to the Education Office shall be made.

However, since January 21, 2019, Governor Regulation Number 32 of 2019, concerning the Position, Organizational Structure, Duties, Functions, and Work Procedures of the Office Branches and Regional Technical Implementation Units of East Nusa Tenggara Province, has been enacted. The Governor Regulation also contains rules regarding the Position, Organizational Structure, Duties, Functions, and Work Procedures of the Office Branches and Regional Technical Implementation Units of East Nusa Tenggara Province. It resulted in a change in the position of UPTD in the education sector. Article 4 paragraph 2 mentions that an official head leads UPTD in the education sector as a functional teacher or tutor under and responsible to the head of the Education Office following statutory regulations. Referring to the Governor Regulation, the position of UPTD in the education sector is determined by each school, and each school principal concurrently serves as the head of UPTD following article 9 paragraph 1.

Thus, there is a change in the workflow and position of UPTD in the education sector. In Regional Regulation Number 9 of 2016, UPTD in the education sector is divided into 12 work areas and is led by a head in charge of carrying out technical activities in several work areas and is responsible to the head of the Education Office. But in Governor Regulation Number 32 of 2019, UPTD in the education sector is divided based on the number of public education units (SMA, SMK, SMALB) and is led by each school principal.

Although the Governor Regulation Number 32 of 2019 was issued based on various studies and through a comprehensive process to decentralize education, increase schoolbased management (SBM), establish schools, increase principal participation as manager, and, in the long term, lead to the electronic data system, at this time its implementation is certainly not easy. It is because East Nusa Tenggara Province covers several islands.

In addition, based on data from the Education and Culture Office, until 2019, East Nusa Tenggara Province had 504 public school units divided into 334 SMA, 155 SMK, and 25 SMALB. With its archipelagic characteristic and many schools to manage, the change in the position of UPTD in the education sector is deemed less effective and efficient related to school services, teachers, education personnel, and the quality of education in each educational unit.

Based on the description above, we are interested in researching the impact of this policy change towards the quality of secondary school education services in East Nusa Tenggara Province. The purpose of this study was to describe and analyze the positive and negative impact of policy implementation that is changing the position of UPTD in the education sector towards the services it provides to teachers and education personnel in East Nusa Tenggara Province.

\section{LITERATURE REVIEW}

The word "policy" in Indonesian is translated into "kebijakan" (Wibawa and Darwin, 2004:31). Islamy (2010:12) defined "policy" as "wisdom". Kamus Besar Bahasa Indonesia

\footnotetext{
3 "Kebijakan" is literal translation of "Policy" in Indonesian.
} 
(KBBI) defines policy as a series of concepts and principles that become the outline and basis of plans in the implementation of a job, leadership, and a statement of ideals, goals, principles, and guidelines for management to achieve goals.

Laswell and Kaplan (in Taufiqorukhman, 2018:19) define public policy as a program of achieving goals and values in directed practices. Syafiie (2006:104) argues that public policy is the answer to a problem--it represents efforts to solve, reduce, and prevent negative things to occur. Public policy becomes an advocate, innovation, and pioneer for goodness.

Many definitions of the public policy are considered too broad, Nugroho (in Taufiqorukhman (2018:20) proposes two characteristics of public policy: (1) public policy must be easy to understand and it refers to activities done to achieve national goals; (2) public policy must be easy to measure because its coverage is clear.

Dunn (2000:137) also states that making public policy must involve 3 (three) elements: policy actors, public policy, and policy environment. These three elements are interdependent.

Dunn (2000) also mentions that a public policy must at least pay attention to 3 (three) things in determining the chosen alternative, including (1) effectiveness, or whether the policy can achieve the formulated targets; (2) efficiency, or whether the policy is balanced with the available resources, and (3) adequacy, or whether the policy is sufficient to solve existing problems.

Based on opinions related to the definition of public policy above, it can be concluded that public policy is a series of systematic actions from various scientific processes and methods, which are determined and implemented by the government to obtain specific goals and benefits, is positive, and able to answer and solve public problems in people's lives, both in the short and long term. The public commonly knows the products of public policy in the form of legislation, presidential decrees, presidential regulations, ministerial regulations, governor regulations, regional regulations and are usually binding and coercive.

The Implementation of Public Policy. Van Mater and Van Horn (in Anggara, 2014:120) state that implementation is an action taken by the government or private officials or groups to achieve the goals outlined in policy decisions. On the other hand, Wahab (1997:53) affirms that implementation is applying policy decisions in the form of laws, necessary executive orders, or decisions or judicial decisions. These decisions identify the problem, clearly state the goals or targets to be achieved, and various ways to structure or manage the implementation process.

Salusu (2003:409) defines implementation as the operationalization of various activities to achieve a specific goal and involving all levels of management from top management to the lowest employees' level. Policy implementation is the stage of applying decisions, such as the articles of legislative law, the issuance of an executive regulation, the issuance of court decisions, or the issuance of regulatory standards and the consequences of policies for the community that affects several aspects of their lives.

As a dynamic process, policymakers need to pay attention to many factors in implementation activities to achieve goals and lead to program goals. Policies should not be made carelessly. Tangkilisan (in Taufiqurokhman, 2018:67) explains three primary and most essential activities in policy implementation activities: (1) interpretation, (2) organization, and (3) application. Abidin (2014:191) said that the implementation of a policy is related to two main factors: (1) internal factors, which include (a) policies to be implemented, and (b) other supporting factors; and (2) external factors, which include (a) environmental conditions, and (b) related parties.

Grindle (in Agustino, 2006:154-157) mentions that the success of implementing a public policy can be measured by achieving the outcomes or goals. Measuring the success of policy implementation can be seen from two aspects: (1) the process, by questioning whether the implementation of the policy is following the determined design regarding policy action, and (2) policy objectives, by considering whether the objectives are achieved or not. This dimension is measured by looking at two factors: (a) impact on society individually and in groups; and (b) the degree of change that occurs, as well as the acceptance of the target group and the changes that take place. 
Edwards III (in Widodo, 2001:12) states that in the process of implementing public policy, it is necessary to pay attention and consider several things to obtain maximum results, including (1) communication, (2) resources, (3) disposition, or attitudes, and (4) bureaucratic structure. From the explanation, it can be concluded that policy implementation is the action taken following problem formulation, arranged in a product or policy to be implemented in public life to solve public problems to reach certain objectives.

The Impact of Public Policy. Dye (in Winarno, 2004: 232-235) adds that the impact of a public policy covers several dimensions, which include:

- impact on public issues (on the target group), whether the impact is expected or not;

- impact on non-target groups that are also called spillover impacts;

- impact on current and future condition; and

- impact on direct costs incurred to finance programs and impact on indirect costs incurred by the public due to a policy (for example, the impact on household expenditures due to resettlement resulting in greater distance to school/workplace).

Anderson (1997:115) states that the policy impact has many dimensions, including:

- expected policy impact (intended consequences) and unexpected policy impact (unintended consequences);

- policy impact on current or future condition;

- policy impact on people (groups) who are not the primary target or objective of the policy (externalities); and

- policy impact on direct costs as experienced by community members, namely the impact in the form of social and economic unrest, inability to achieve policy objectives, and so on.

Anderson (in Abidin, 2014:57) argues that a policy made and implemented by the government may not achieve its goal or not have a positive impact as expected during the preparation process; even though during the implementation process it succeeds in realizing the output, but it fails to achieve the outcomes. The factors causing failure in achieving outcomes include (1) inadequate resources, (2) inappropriate process or method of implementation, (3) discrepancy with public needs or problems, (4) ways to respond to policies that can reduce the desired impact, (5) disproportionate policy objectives, (6) the nature of the problem to be solved, (7) the high costs incurred-higher than the problem, (8) too many public problems that cannot be solved, and (9) the emergence of another problem.

Based on the description above, we conclude that policies, rules, or actions made and implemented by policymakers or stakeholders will have a good impact and can answer public problems if those policies, rules, or actions are adequately prepared and consider various aspects. Good public policy following the objectives will create good outcomes and have a positive impact. Thus, several methods can be used to determine the impact of the policy implementation on the change of position in UPTD in the education sector in East Nusa Tenggara Province.

Indicators of Public Service Quality. Zaurah (in Tjiptono, 2005:28) explains that service quality is conformance to specification, where this quality is seen as the degree of excellence to be achieved. Continuous control in achieving excellence is carried out to meet the needs of service users.

Meanwhile, according to Zeithami and Barry (in Tjiptono, 2005:63), ten dimensions must be considered to measure service quality, namely:

- tangible, which consists of various kinds of physical facilities, equipment, personnel, and communications;

- reliable, which is related to the unit's ability to create services;

- responsiveness, which is the willingness or readiness to help consumers;

- competence, which is a requirement that must be possessed related to knowledge and skills in providing services;

- courtesy, which relates to behavior or attitude of being polite, friendly, helpful to consumers;

- credibility, which is the nature of being honest and trustworthy; 
- access, including the ease of being contacted;

- communication, which means providing information to customers in a language they understand and always listening to customer suggestions and complaints;

- security, which is defined as being safe from danger, risk, and doubt; and

- understanding customer needs.

Zeithami and Barry (in Tjiptono, 2005) continue that of the ten quality indicators, the measure of customer satisfaction lies in five dimensions of service quality which consist of:

- tangibles, which are related to physical appearance in the form of physical facilities, attractiveness, waiting rooms, computerized administration, and neatness;

- reliability, which relates to the reliability and skills of the service providers;

- responsiveness, which is related to the ability of service providers to assist and provide appropriate services appropriately, quickly and carefully respond to complaints from service recipients;

- assurance, which is the ability of service providers to maintain trust in service recipients; and

- empathy, which is the firm but attentive attitude of service providers towards service recipients.

Meanwhile, Tjiptono (2005:95) reveals that good quality services can be assessed from (1) service timeliness, (2) service accuracy, (3) courtesy and friendliness, (4) convenience in accessing services, (5) ease of getting services, and (6) service attributes or supporting facilities.

Regional Technical Implementation Unit (UPTD) in the Education Sector. UPTD is an abbreviation of Unit Pelaksana Teknis Daerah (Regional Technical Implementation Unit). Regional Regulation Number 9 of 2016 states two types of UPTD, namely UPTD Dinas (Office) and UPTD Badan (Agency). UPTD in the education sector is under the office coordination that implements government policies in the education sector and is an extension of the Education Office in implementing regulations and policies in the education sector in their respective work areas.

According to the Regulation of the Minister of Home Affairs Number 12 of 2017 concerning Guidelines for the Establishment and Classification of Office Branches and UPTD in the education sector, the executor of education programs in the work area acts as a coach, developer, supervisor, assessor, coordinator, and advisor for education at the school level, both formal and non-formal, to realize the vision and mission of East Nusa Tenggara Provincial Government, especially in the education sector. The duties and functions of UPTD in the education sector include planning, coordinating, controlling, and evaluating the implementation of education at SMA, SMK, and SMALB in regencies or cities based on policies set by the governor. Apart from being the executor of the tasks described above, UPTD in the education sector also has additional duties as executor of administrative matters related to general, financial, and reporting equipment and personnel affairs.

In carrying out its duties as regulated in Governor Regulation Number 32 of 2019 article 9 paragraph 2, UPTD in the education sector has an organizational structure consisting of (1) Head of UPTD, (2) Administration Division, and (3) Sections, which consists of sections of SMA, SMK, and SLB. The Head of UPTD in the education sector is responsible to the Head of the Education Office. From the overall explanation related to UPTD above, it can be concluded that UPTD in the education sector is an official organization formed based on regional laws and regulations established by regional heads to help ease the burden of the Education Office in implementing technical activities and improving services of education units at SMA, SMK, and SMALB levels located in several areas. UPTD in the education sector has to carry out work following their duties and functions and the rules that have been set.

\section{METHODS OF RESEARCH}

This study used a descriptive method with a qualitative approach. The focus of this 
research was; (1) the positive impact of policy implementation that is changing the position of UPTD in the education sector towards the services it provides to teachers and education personnel in East Nusa Tenggara Province) and (2) the negative impact of policy implementation that is changing the position of UPTD in the education sector towards the services it provides to teachers and education personnel in East Nusa Tenggara Province. The study was carried out in schools in East Nusa Tenggara Province with certain considerations, including (1) the area was the working area of the UPTD in the education sector before the implementation of Governor Regulation Number 32 of 2019; (2) geographically, these areas may represent the Timor Mainland, Flores, and the archipelagic region; and (3) it is the area where teachers and students are mostly distributed, so it is expected that it can provide an overview of the problem being studied. Data for this study was collected using interviews, documentation, and observation. Sources of data come from primary data and secondary data. The researchers used the data analysis technique proposed by Miles and Huberman (2007). Data validation was done using the triangulation technique.

\section{RESULTS AND DISCUSSION}

The research results came from 54 public SMA, SMK, and SMALB spread across six regencies or cities within East Nusa Tenggara Province. This research was conducted to determine whether policy implementation of a position change on UPTD in the education sector had a positive or negative impact.

Positive Impacts:

Services for Teachers and Education Personnel Become Centralized. Based on the data obtained from 232 informants spread over six regencies or cities in East Nusa Tenggara Province, most of the informants stated that the change in the position of UPTD in the education sector, as regulated by the Governor Regulation Number 32 of 2019, had a positive impact. They stated that the service to teachers became centralized, one-stop, and did not require a long bureaucratic process with this policy. Thus, all teaching staff on duty at each school could immediately get services without going through the procedures in the UPTD in the education sector in their area so that the services were more effective.

This condition is following what has been formulated by the Ministry of State Apparatus Utilization and Bureaucratic Reform Number 15 of 2014 concerning Service Standard Guidelines described in Chapter II, where Service Standards consist of (1) service procedures, (2) service products, (3) service time, and (4) service cost.

Increased Service Quality to Teachers. In addition to making services centralized, one of the positive impacts felt by teachers from the implementation of Governor Regulation Number 32 of 2019 is the improvement of the quality of services for teachers. With the Governor Regulation, most of the informants stated that the service in the Education Office was better than the service before the Governor Regulation was implemented.

Based on the information obtained, most of the informants stated that the service at the education office was better in terms of reliability and responsiveness of the staff. The education office staff does the service covering the ten indicators described by Parasuraman, Zeithami, and Barry (in Tjiptono, 2005:47), which consist of (1) reliability, (2) responsiveness, (3) competence, (4) access, (5) courtesy, (6) communication, (7) trust, (8) security, (9) understanding, and (10) evidence.

Better participation of education personnel. So far, many personnel administration matters have been done by teachers themselves. Based on research results, the policy also positively impacted increasing the role and performance of education personnel previously considered less professional. The increased participation of education personnel followed the position of education personnel as regulated in Law Number 20 of 2003 concerning the National Education System, which states that Educational Personnel is technical personnel whose work requires technical, operational or administrative skills.

Therefore, the presence of education personnel in each school is very important to ensure that all school administrative matters can run well and create quality services in each 
educational unit.

Negative Impacts:

Increased Workload for Teachers. The study results indicated that one of the direct impacts was the increase in teachers' workload. Law Number 14 of 2005 concerning Teachers and Lecturers explains that teachers are professionals with the main task of educating, guiding, training, and evaluating students with a workload of 24 hours per week and can be given additional relevant tasks such as being the head of the laboratory, viceprincipal, or teaching other subjects that are linear with the teaching certificate.

However, the change in the position of UPTD in the education sector as regulated in Governor Regulation Number 32 of 2019 turned out to impact the workload of teachers in each education unit because many educational units did not have education personnel in charge of organizing and managing school administration. As a result, many additional irrelevant tasks, such as managing the School Operational Assistance Funds, being a library manager, teacher on duty, and so forth, are given to teachers.

This condition is certainly in contrast to the idea conveyed by Anderson (1997:113) about public policy-it is an action that has the purpose of solving a problem. However, this change in the position of UPTD in the education sector turned out to create another problem. One of the objectives of Governor Regulation Number 32 of 2019 is to regulate bureaucratic governance, especially in the Education and Culture Office, by optimizing the functions of school principals and education personnel in each educational unit.

Therefore, it can be concluded that the change in position of UPTD in the education sector had a negative impact on increasing the workload for teachers.

Disruption of Teaching and Learning Activities. The research results showed that the implementation of Governor Regulation Number 32 of 2019 has a negative impact on the teaching and learning process in each education unit in East Nusa Tenggara Province. Many teachers are still busy with school administration and have additional workloads that are not relevant to their main duties as educators. Therefore, following the contents of article 20 paragraph 1 of Law Number 14 of 2005 on the rights and obligations, teachers must design, implement, assess, and evaluate learning activities. However, if the teacher is preoccupied with administrative matters or given an irrelevant workload, it will greatly disrupt the teaching and learning process.

The Decline of the School Supervision System. The success of schools in designing and implementing the learning process, assessment, quality improvement, and school management cannot be separated from a good education supervision system, whether carried out directly by the Education and Culture Office, UPTD in the education sector, school supervisors and school committees in each education unit. Since the beginning of 2019, East Nusa Tenggara Provincial Government, with Governor Regulation Number 32 of 2019 , stipulates that school supervision is assigned to each supervisory coordinator who is an extension of the education office.

However, research data showed that the availability of supervisors in the regions did not match the required ratio, or in other words, there was a shortage of school supervisors, which resulted in supervisors getting workload exceeding the workload determined by law. As a result, many schools are not supervised either by the education office or by supervisors.

In addition, this can refer to Government Regulation Number 74 of 2008, which regulates procedures, duties, and functions related to teachers and supervisors. The regulation clearly states that a school supervisor is a career position that is only filled or occupied by a teacher with the status of a civil servant with the main task of carrying out managerial supervision and academic supervision of at least ten schools and a maximum of 15 schools and 24 (twenty-four) hours of a face-to-face meeting by considering the number of schools and teachers.

Curriculum Targets Are Not Achieved. The more tasks assigned to the teacher or the more often a teacher leaves the teaching and learning activities, the more difficult it is to achieve curriculum targets. Teachers have felt this condition since Governor Regulation Number 32 of 2019 began to be implemented in early 2019. From the information during interviews, most of the informants admitted that they lost a lot of teaching time when they 
had to take care of administrative tasks, which greatly impacted the curriculum targets.

Increased School Budget. Each education unit only has two sources of income, namely the School Operational Assistance Fund and the Committee Contribution Fund. The first fund is determined according to the number of students enrolled in the school and finance the implementation of the eight) National Education Standards. Although it includes a budget for management standards, the budget allocated is very limited because most of the School Operational Assistance Fund is used for developing content standards, process standards, graduate competency standards, and assessment standards. Therefore, it will not be very easy for the principal, teachers, and education personnel to pay for official travel or administration activities, especially for schools outside Kupang City, located far from the service center.

This problem is certainly not in line with administrative capability, which concerns the ability of the administration to support the policy, as stated by Sofian Effendi (2001:68) regarding the criteria for public policy. It is also related to the opinion of Thomas $R$. Dye (in Winarno, 2004:232-235) about policy impact, especially regarding direct costs that the public must incur due to the existence of a Governor Regulation made by the government.

Education services become ineffective, inefficient, and not economical. From the interviews, 87 informants (37.5\%) stated that education services were inefficient due to the difficulty of access to services only after one year after the implementation of the policy. Related to the economy, $82.7 \%$ informants stated that educational services were very uneconomical because it required higher costs to access these services because respondents had to travel long distances and provide a budget for transportation and accommodation.

If we refer to Law Number 25 of 2009 Article 21 concerning service standards, the condition was not good. It took long time for task completion, higher fees or costs, with no service guarantees, and uncertain safety of services for education personnel to access.

Difficult Service Access. From the interviews $87 \%$ of informants stated that since the enactment of Governor Regulation Number 32 of 2019, access to services for centralized education personnel had become increasingly difficult. The difficulty in accessing services was also caused by limited school budgets, educational background, age, and employment status of education personnel.

The difficulty in obtaining services certainly brought an systemic impact to education in East Nusa Tenggara Province. This condition is also certainly not in line with the principles of public service providers as described in the Decree of the Ministry of Administrative and Bureaucratic Reform of the Republic of Indonesia Number 63 of 2003 on the principles of service delivery as a guide in supporting public service activities. The principle is related to ease of access, adequate service facilities, and convenience in utilizing telecommunications and information technology.

\section{CONCLUSION}

Based on the findings, it can be concluded that the policy implementation of a change in the position of UPTD in the education sector on secondary school education services in East Nusa Tenggara Province had a negative impact assessed on these dimensions: (1) impact on the target groups; (2) impact on non-target groups; (3) impact on current and future condition; and (4) impact on costs. include:

In addition, other factors that have contributed to the failure of this governor regulation

- Communication was not running well. The majority of school principals, teachers, education personnel, and school supervisors did not fully understand the intent and purpose of Governor Regulation Number 32 of 2019. In addition, to date, most of the informants only heard but never read or had a printout or document of Governor Regulation Number 32 of 2019. Thus, they were hesitant to take any action;

- Governor Regulation Regulation Number 32 of 2019 is expected to increase the participation of administrative staff in each educational unit. However, the policy did 
not have a significant impact on their duties and functions. All school administrative matters such as personnel data, correspondence, student documents, assets, and so on are the duties of education personnel. However, teachers do these tasks to date because most of the education units in East Nusa Tenggara Province do not have qualified education personnel, both in educational background and the ability to manage school administration;

- The geographical condition of the East Nusa Tenggara Province is also considered to have contributed to the ineffectiveness of this policy. Areas outside Kupang City find it difficult to access services, as it takes a lot of time and money. It is exacerbated by a lack of facilities such as roads, transportation modes, communication networks, and lighting in each area.

\section{SUGGESTIONS}

Based on findings, suggestions given to the East Nusa Tenggara Provincial Government are as follows:

- The provincial government needs to disseminate information to all school principals, teachers, and education personnel related to the implementation of the policy because most of them do not understand the contents of Governor Regulation Number 32 of 2019. The document of Governor Regulation Number 32 of 2019 never reaches each educational unit, especially the research location. As a result, there are still many schools that follow the old system;

- Based on the results of the study, it was found that almost $80 \%$ of Public SMA, SMK, and SMALB in East Nusa Tenggara Province did not have education personnel or administrative personnel. As such, the change in the position of UPTD in the education sector only added the workload of teachers and brought negative impacts on education quality, especially in teaching and learning activities. Because teacher's workload increased, the curriculum target was not achieved and the assessment results were low when compared to private schools in East Nusa Tenggara Province;

- The East Nusa Tenggara Provincial Government needs to recruit school supervisors because it was found that each regency where the research was conducted had only oneor two supervisors. As a consequence, supervisors' workload was far too high. If this condition continued to happen, it would affect the management and supervision of the school;

- The East Nusa Tenggara Provincial Government needs to evaluate this policy by considering several things, including (1) the geographical condition of East Nusa Tenggara Province, which is an archipelago; (2) human resources in education units, especially education personnel; (3) inadequate facilities and infrastructure in schools, especially in schools located in remote areas; and (4) accessibility such as road conditions, transportation, distance, and internet access, which results in many teachers having difficulties in accessing services at the Education Office.

\section{REFERENCES}

1. Wibawa, Samodra and Darwin, Muhadjir. 2004. Evaluasi Kebijakan Publik. Raja Grafindo Persada. Jakarta.

2. Islamy, M.Irfan. 2010. Prinsip-prinsip Perumusan Kebijakan Negara. Bumi Aksara. Jakarta.

3. Taufiqurokhman. 2018. Perkembangan Manajemen Pelayanan Publik Teori and Perkembangan Manajemen Pelayanan Publik. UMJ Press. Jakarta.

4. Dunn, William N. 2000. Pengantar Analisis Kebijakan Publik (Terjemahan), Edisi Kedua. Gajah Mada University Press. Yogyakarta.

5. Anggara, Sahya. 2014. Kebijakan Publik. CV PUSTAKA SETIA. Bandung.

6. Wahab, Abdul Solichin. 1997. Analisis Kebijaksanaan, Dari Formulasi Keimplementasi Kebijaksanaan Negara. PT Bumi Aksara. Jakarta. 
7. Salusu, Jonathan. 2003. Pengambilan Keputusan Strategik untuk Organisasi Publik and Organisasi Nonprofit. Grasindo. Jakarta.

8. Abidin, Said Zainal. 2014. Kebijakan Publik. Salemba Humanika. Jakarta.

9. Agustino, Leo. 2006. Politik and Kebijkan Publik. AIPI Bandung and Puslit KP2W Lemlit Unpad. Bandung.

10. Widodo, Joko. 2001. Good Governance: Telaah dari DimensiAkuntabilitas and Kontrol Birokrasi pada Era Desentralisasi danOtonomi Daerah. Insan Cendikia. Jakarta.

11. Winarno, Budi. 2004. Teori and Proses Kebijakan Publik. Media Pressindo. Yogyakarta.

12. Anderson, James, A.1997. Public Policy Making Third Edition. Houghton Miffin Company. USA.

13. Tjiptono, Fandi. 2005. Managemen Jasa.ANDI: YogyakartaAnderson, James, A.1997. Public Policy Making Third Edition. Houghton Miffin Company. USA.

14. Syafiie, Inu Kencana. 2006. Ilmu Administrasi Publik. PT. Rineka Cipta. Jakarta.

15. Miles, Mattew B and Amichael Huberman. 2007. Analisis Data Kualitatif Buku Sumber tentang Metode-Metode Baru. Terjemahan Tjetjep Rohendi Rohisi. Universitas Indonesia. Jakarta.

16. Winarno, Budi. 2004. Teori and Proses Kebijakan Publik. Media Pressindo. Yogyakarta. 